\title{
ENVIRONMENTALLY INDUCED CHANGES IN RIBOSOMAL RNA CISTRON NUMBER: PURPORTED LACK OF CORRELATION WITH PHENOTYPE-A REPLY
}

\author{
C. A. CULLIS \\ John Innes Institute, Colney Lane, Norwich NR4 7UH
}

Received 21.i.77

Frankham's (1977) statistical treatment of my published data (Cullis, 1976) is valid. I would like to make two points concerning the conclusion " the changes described in rRNA gene redundancy may be a primary event in the induction of heritable changes in flax" quoted from Timmis and Ingle (1975). First, there is no evidence that a change in rRNA gene number is a primary event in the induction of heritable changes in flax. Changes in a number of DNA sequences occur, of which the rRNA genes are but one example, and a model for their induction has recently been proposed (Cullis, 1977). Secondly, Timmis and Ingle (1975) state that " the induction of $\mathrm{L}_{0}$ therefore does not involve rRNA genes ". In both their work and my own (Cullis, 1976) the $\mathrm{PI}$ and the $\mathrm{L}_{0}$ forms have identical numbers of rRNA genes.

The possibility of chimaeras being involved cannot be entirely eliminated. To do this would require measurements on single cells of both nuclear DNA and ribosomal cistron number, and although theoretically possible, this would be difficult to achieve.

\section{ReFERENCES}

CULLIS, c. A. 1976. Environmentally induced changes in ribosomal RNA cistron number in flax. Heredity, 36, 73-79.

Cullis, c. A. 1977. Molecular aspects of the environmental induction of heritable changes in flax. Heredity, 38, 129-154.

FRANKHAM, R. 1977. Environmentally induced changes in ribosomal RNA cistron number: purported lack of correlation with nuclear DNA and phenotype. Heredity, 39, 175-176.

TIMMIS, J. N., AND INGLE, J. 1975. The status of ribosomal RNA genes during nuclear DNA reversion in flax. Biochem. Genet., 13, 629-634. 